\title{
Winter Wheat Cultivars with Temperature-Sensitive Resistance to Wheat streak mosaic virus Do Not Recover from Early-Season Infections
}

Jacob A. Price and Angela R. Simmons, Texas A\&M AgriLife Research and Extension, Amarillo 79106; Arash Rashed, University of Idaho, Aberdeen Research \& Extension Center, Aberdeen 83210; and Fekede Workneh and Charles M. Rush, Texas A\&M AgriLife Research and Extension, Amarillo

\begin{abstract}
Price, J. A., Simmons, A. R., Rashed, A., Workneh, F., and Rush, C. M. 2014. Winter wheat cultivars with temperature-sensitive resistance to Wheat streak mosaic virus do not recover from early-season infections. Plant Dis. 98:525-531.

Wheat streak mosaic virus (WSMV), Triticum mosaic virus, and Wheat mosaic virus, all vectored by the wheat curl mite Aceria tosichella Keifer, frequently cause devastating losses to winter wheat production throughout the central and western Great Plains. Resistant 'Mace' and 'RonL are commercially available and contain the wsm1 and wsm2 genes, respectively, for resistance to WSMV. However, the resistance in these cultivars is temperature sensitive, ineffective above $27^{\circ} \mathrm{C}$, and does not protect against the other common wheat viruses. The majority of winter wheat in the Southern Great Plains is planted in early fall as a dual-purpose crop for both grazing and grain production. Early planting exposes wheat plants to warmer temperatures above the threshold for effective resistance. Studies were conducted to determine whether the resistance found in these cultivars would give infected plants the ability to recover as temperatures cooled to a range conducive to effective genetic resistance. RonL, Mace, 'TAM 111', 'TAM 112', and

peratures above the resistance threshold. After the initial 4-week infection period, plants were subjected to progressively cooler temperatures during the winter months, well below the resistance threshold Throughout the study, plant samples were taken to quantify virus titer and mite populations. Resistant RonL and Mace, which became severely infected during the initial infection period, were not able to recover even when temperatures dropped below the resistance threshold. However, TAM 112 showed resistance to WSMV but, more importantly, it also showed resistance to the wheat curl mite, because the mite population in this cultivar was significantly lower than on all other cultivars. The results of this study are significant in that they represent the first evidence of quantitative resistance to both WSMV and the wheat curl mite in a single wheat cultivar. Resistance to the wheat curl mite has potential to reduce losses to all mite-vectored virus diseases of wheat and not just WSMV.
\end{abstract} 'Karl 92' wheat were infested with WSMV viruliferous mites at tem-
Wheat is an important crop grown throughout the Great Plains region of the United States and, in the southwestern part of this region, serves as a dual-purpose crop for both grazing and grain production. Early planting of dual-purpose wheat, in late August through mid-September, is a common practice because it provides a longer period of forage production for grazing. Although early planting of dual-purpose wheat is optimal for forage production, it also exposes wheat to warmer late-summer or early-fall temperatures and, thus, a longer period of exposure to a variety of insect pests and pathogens. Among these pathogens, the mite-vectored viruses Wheat streak mosaic virus (WSMV), Triticum mosaic virus (TriMV) (2), and Wheat mosaic virus, formerly High plains virus (19), cause devastating losses throughout the Great Plains. WSMV, in particular, has been shown to cause devastating losses in Northern Texas (23). Studies conducted by Burrows et al. (1) determined that these viruses not only occur individually throughout the Great Plains from Texas to North Dakota and into Canada but also occur as co-infections, particularly in the case of WSMV and TriMV. Disease symptoms in plants infected by these viruses are characterized by mosaic streaking patterns and stunting, which ultimately can lead to necrosis and plant death. Severe infections causing significant yield losses are particularly common during early-season infections, when temperatures are relatively higher and plants are at their early developmental stages (7). Disease symptoms are also known to increase in severity during multiple infections, particularly in the case of co-infections by WSMV and TriMV (22), and can be detected within single samples by molecular testing (13).

Corresponding author: J. A. Price, E-mail: japrice@ag.tamu.edu

Accepted for publication 25 October 2013.

http://dx.doi.org/10.1094/PDIS-04-13-0455-RE

(C) 2014 The American Phytopathological Society
All three members of this virus complex are transmitted by the microscopic wheat curl mite Aceria tosichella Keifer (Prostigmata: Eriophyoidae) $(15,16,20)$. Wheat curl mites oversummer in volunteer wheat and some perennial grasses between winter wheat seasons (5). These hosts serve as a reservoir for both the viral pathogens and mite vectors, which are blown by winds from these areas into agricultural fields and then transmit the viruses during feeding. As wheat curl mite populations build, they move from the site of initial infestation throughout the field, creating a characteristic disease gradient, from very severe on the edge of the field at the point of origin to less severe with distance into the field. Studies by Workneh et al. (24) examined disease severity and its effects on water use and yield along natural disease gradients within WSMVinfected fields. As disease severity increased, a decrease in water use efficiency and grain yield was observed. The effects of disease were greatest at the site of initial infection, typically the edge of a field, and progressively decreased toward the interior of the field (25). Findings by Price et al. (14) demonstrated that the reductions in water use efficiency and grain yield in infected plants were accompanied by severe reductions in root development and overall root biomass. The reduced root systems of infected plants were not able to uptake water as efficiently from the soil profile, increasing soil volumetric water content and reducing water use efficiency and grain yield.

Two resistant winter wheat cultivars, 'Mace' and 'RonL', which contain $w s m 1$ and $w s m 2$ resistance genes, respectively, have been developed for control of WSMV. Although these two cultivars have relatively strong resistance to WSMV, their resistance is temperature sensitive, and breaks down at temperatures above $24^{\circ} \mathrm{C}$ for RonL (18) and above $27^{\circ} \mathrm{C}$ for Mace (17). Once temperatures rise above the threshold, these cultivars display the same susceptibility to infection and disease development as those that do not carry the resistance gene. Little is known about the underlying mechanism of virus resistance conferred by the wsm 1 and wsm 2 genes following the mite-mediated transmission. To date, studies have evaluated 
genetic resistance at steady temperatures and through mechanical virus inoculation to determine their effectiveness at high temperatures $(17,18)$. However, under natural circumstances, ambient temperatures may fluctuate dramatically.

Throughout the southwestern Great Plains, late August to early September plantings of dual-purpose winter wheat coincide with high temperatures and, thus, potential for early infection of the crop by mite-vectored viruses is significant, even with resistant cultivars. However, as the season progresses, average temperatures cool and soon fall to a range that is conducive to effective genetic resistance. It is unknown whether, at these lower temperatures, genes that confer resistance to WSMV could again become effective, allowing a reduction in virus titer and recovery from initial infection. If resistant genes became effective at lower temperatures, a reduction in virus titer could be accompanied by increased plant health which, subsequently, would lead to plant recovery. Such a recovery would not be expected in cultivars lacking the resistant genes. The possible ability of resistant cultivars to recover from early infection by WSMV was an important question for producers trying to minimize losses to wheat streak mosaic (WSM). Therefore, the present study was conducted to address this question by quantifying variations in virus titer in a number of commercially available cultivars during thermal fluctuations that followed initial infection with WSMV at high temperatures, above the resistance threshold.

\section{Materials and Methods}

Planting and infestation by viruliferous wheat curl mites. All experiments were conducted at the Texas A\&M AgriLife Research and Extension Experiment Station, Bushland. The study was conducted with the two varieties containing genetic resistance genes $w s m 2$ and $w s m 1$, RonL and Mace, and also included two regionally adapted and widely grown winter wheat cultivars, 'TAM 111' and 'TAM 112'. Wheat cultivar Karl 92 was included as a susceptible control. For each cultivar, seed were planted in individual 3.7-liter pots containing general potting mix, allowed to germinate, and then thinned to four plants per pot. Plants were grown in a 2.9-by2.4-by-2.1-m walk-in growth chamber, maintained at $28^{\circ} \mathrm{C}$, with photosynthetically active radiation of approximately $100 \mu \mathrm{mol} \mathrm{m} \mathrm{m}^{-2}$ $\mathrm{s}^{-1}$. Each pot was fertilized uniformly and watered as needed. Selected cultivars were planted in a randomized complete block design containing eight pot-replications of each cultivar and infested with viruliferous wheat curl mites.

Traditionally, mechanical inoculations with WSMV have been used to infect plants and to evaluate the impact of elevated temperatures on genetic resistance $(17,18)$. However, in this study, infective wheat curl mites were used to infect plants with WSMV. This allowed us to monitor and compare vector population fluctuations and virus titer development among the different wheat cultivars. Four weeks after planting, plants were infested with 20 to 30 viruliferous wheat curl mites, collected from a colony maintained on WSMV-infected plants grown under greenhouse conditions for approximately 2 years. Host plants used for the infestation process were verified by enzyme-linked immunosorbent assay (ELISA; Agdia Inc.) to be positive for WSMV at the time of mite collection. Leaves from host plants that displayed leaf rolling, indicative of heavy mite feeding, were collected and examined under a dissect-

Table 1. Average temperatures between collections for experiments 1 and 2

\begin{tabular}{lcc}
\hline & \multicolumn{2}{c}{ Average temperatures $\left({ }^{\circ} \mathbf{C}\right)$} \\
\cline { 2 - 3 } Collection $^{\mathbf{a}}$ & Experiment 1 & Experiment 2 \\
\hline First & 27 & 27 \\
Second & 18 & 18 \\
Third & 7 & 5 \\
Fourth & 12 & 18 \\
Fifth & 17 & NA $^{\mathrm{b}}$ \\
\hline
\end{tabular}

${ }^{a}$ Collections were taken every 4 weeks after infestation.

${ }^{\mathrm{b}}$ Experiment 2 was harvested after the fourth collection, before plant death. ing scope at $\times 40$ until 20 to 30 mites were counted. The leaf area containing the mites was then excised and placed in a petri dish Once a sufficient number of infested leaf pieces were collected, study plants were infested by placing a single section of the miteinfested tissue into the leaf whorl of one tiller within each pot. Approximately 3 weeks after infestation, tillers were examined within random pots to verify that mite populations were moving to the other plants. Three additional pot replicates of each cultivar remained noninfested to serve as noninfested controls. After infestation, plants were maintained at $28^{\circ} \mathrm{C}$ to enhance infection by WSMV. Four weeks after infestation, plants were moved outside, under winter conditions within a greenhouse breezeway on 12 January 2012. Beginning 4 weeks after infestation, five separate collections of three individual tillers were taken from different areas within each pot approximately 4 weeks apart for both virus titer quantification and mite counts. Individual tillers were collected by separating the entire tiller from the plant for processing. Daily temperatures were monitored using a Hobo (Onset Computer Corporation, Inc.) to calculate the average daily temperature plants were exposed to during the time between each consecutive collection (Table 1). During the last collection, many of the most severely infected plants were beginning to die; therefore, the study was terminated. To obtain root and shoot tissue weights, at the conclusion of each experiment all plants were removed from the pots and shoot tissue was separated from the crown and placed in a paper bags. The root system was then washed free of all soil and organic matter and collected in a separate paper bag. Collected tissues were then placed in a hotbox at $45^{\circ} \mathrm{C}$ for $72 \mathrm{~h}$ to obtain root and shoot dry biomass.

The experiment was repeated during summer 2012 and, in order to replicate temperature fluctuations, it was conducted entirely within the growth chamber. The same collection times and average temperatures similar to the first study were maintained between each collection (Table 1). During the first study, removal of potting soil from the root system to obtain dry biomass weights proved to be difficult due to large amounts of organic matter contained within the potting mix. Therefore, in the second study, a clay mixture of Turface brand, Quickdry (Turface Athletics) was used instead. The study was terminated and plants were harvested after four collections, before plant death. Due to a lack of additional facilities for maintaining negative controls under the same environmental conditions, negative controls were maintained on raised shelves approximately $1 \mathrm{~m}$ above the infested pots in the same growth chamber.

Sample preparation for mite/virus quantification. During processing, leaves of each of the three tillers were separated and tightly coiled leaves were split to facilitate removal of mites during the washing process. A section of the first fully expanded leaf was also collected from each tiller to create composite samples of 0.8 to $1.0 \mathrm{~g}$ of tissue to be used for RNA extraction and real-time polymerase chain reaction (PCR), to quantify WSMV titer. These samples were then placed in a $2.0-\mathrm{ml}$ centrifuge tube with a $5-\mathrm{mm}$ stainless-steel bead and frozen at $-80^{\circ} \mathrm{C}$ until further processing. The remaining tissue was placed in a 50-ml falcon tube, and a solution of $60 \%$ ethanol/water and $25 \mathrm{ppm}$ Aquet Laboratory detergent (Bel-Art Products) was added to the tube. Samples were stored at $4{ }^{\circ} \mathrm{C}$ until further processing for mite quantification.

To evaluate mite numbers, the samples with $60 \%$ ethanol were vortexed for $2 \mathrm{~min}$ to release mites from the tissue. Initially, mite counting was conducted by vacuuming the entire sample onto black filter paper and counting all the mites on the filter. However, this proved to be increasingly difficult and time consuming due to the large numbers of mites found during sampling. The enormous reproductive potential of the wheat curl mite has been documented in other studies (21) and reported to increase in numbers which preclude successful counting after only 8 days post infestation (6). Therefore, a dilution method was developed to increase efficiency and was compared with counting the entire sample. To evaluate the new method, samples containing different numbers of wheat curl mites were washed from infested tissue and counted. The same 
sample was then placed in a falcon tube containing ethanol solution and counted using the following method. The dilution method was found to be $93 \%$ accurate in estimating mite numbers and was used through the course of the study. The vortexed mite/ethanol suspension was poured into a separate 50-ml falcon tube and the total volume of solution was recorded. The suspension was shaken vigorously for $15 \mathrm{~s}$ to insure that a homogeneous mite/ethanol suspension was created. Three separate samples of $500 \mu \mathrm{l}$ were then removed from the suspension and vacuum filtered onto black filter paper previously marked with three counting arenas (circular grids) with a diameter of $2.5 \mathrm{~cm}$ to facilitate counting. Each arena was then counted under a dissecting scope at $\times 40$ to 50 magnification and averaged to calculate the average number of mites per milliliter of solution. The average number of mites per milliliter was then multiplied by the total volume of mite/ethanol suspension to determine total mite number for each sample.

RNA extraction and virus quantification by real-time PCR. Plant tissue samples were kept frozen in liquid nitrogen and then homogenized on high speed, using a Talboys High-Throughput Homogenizer, for $1 \mathrm{~min} 30 \mathrm{~s}$. RNA extraction was then conducted by the addition of buffers similar to that of Nanassy et al. (12) with minor changes. After grinding, $500 \mu \mathrm{l}$ of $5 \mathrm{M}$ guanidine thiocyanate, $20 \mathrm{mM}$ EDTA, $1 \%$ Triton $\mathrm{X}-100$, and $0.1 \mathrm{M}$ Tris-chloride ( $\mathrm{pH}$ 6.4) solution was added to each sample, vortexed, and centrifuged for $15 \mathrm{~min}$ at 13,000 rpm. The supernatant was then removed and placed in a new 1.7-ml centrifuge tube with 1.5 vol of $100 \%$ ethanol, mixed, and incubated for $1 \mathrm{~h}$ at $-20^{\circ} \mathrm{C}$. After incubation, the samples were vacuumed through UltraClean Plant RNA isolation spin column (Mo Bio Laboratories Inc.) attached to a vacuum manifold. Columns were washed with $5 \mathrm{M}$ guanidine thiocyanate, $20 \mathrm{mM}$ EDTA, and 0.1 M Tris-chloride ( $\mathrm{pH}$ 6.4) solution, then washed twice with $560 \mu \mathrm{l}$ of a solution containing $2.5 \mathrm{mM}$ EDTA, $50 \mathrm{mM} \mathrm{NaCl}, 10 \mathrm{mM}$ Tris-chloride (pH 7.4), and 50\% ethanol. To remove excess salts, columns were washed twice with $650 \mu \mathrm{l}$ of
$75 \%$ ethanol and dried by centrifugation at $13,000 \mathrm{rpm}$ for $3 \mathrm{~min}$. RNA was eluted with $50 \mu$ of RNase-free water and stored at $-80^{\circ} \mathrm{C}$. Before real-time PCR, total nucleic acids were quantified and checked for purity using a GeneQuant Pro spectrophotometer (GE Healthcare), and the 260/280 ratio for all samples was between 1.8 and 2.0. Samples were then diluted to $25 \mathrm{ng} / \mu \mathrm{l}$ of template RNA for reverse transcription using a M-MuLV Reverse Transcriptase Kit (New England Biolabs Inc.), following the manufacturer's suggested protocol with random primers. Relative quantification (RQ) was conducted using an ABI 7000 Sequence detection system (Applied Biosystems). Primers WSM8402 (5'GAC ACG GGA GGA GCT AAG ACA GG-3') and WSM8499 (5'-CCT GGT GTC TGA TCT TGC ACA T-3') were used with probe WSMp8461 (6FAM-5'CACATCGAATCCC3'-MGBNFQ) for detection by amplification of a 119-bp amplicon. Primer working concentrations of $600 \mathrm{nM}$ and probe concentrations of $250 \mathrm{nM}$ were used for detection of the coat protein region of WSMV (GenBank accession number AF057533). A reaction cycle of $95^{\circ} \mathrm{C}$ for $10 \mathrm{~min}$ was followed by annealing for 40 cycles at $60^{\circ} \mathrm{C}$ for $1 \mathrm{~min}$. An 18S ribosomal control from Applied Biosystems was included in the reaction as an endogenous control for relative quantification (RQ) comparison of cycle threshold $\left(\mathrm{C}_{\mathrm{t}}\right)$ values using the $\Delta \Delta \mathrm{C}_{\mathrm{t}}$ method, by comparison of each sample with a calibrator sample positive for WSMV. Each sample was replicated and $2 \mu \mathrm{l}$ of cDNA template was added to each reaction. The WSMV calibrator sample was created by addition of a PCR fragment of WSMV that contained the target region for real-time amplification. PCR fragments were created using primers WSM7285 (5'-TGCCAA AGCTGTGGTTGATG-3') and WSM8499. Amplification was conducted using a Platinum Taq High-Fidelity PCR polymerase (Invitrogen) with reaction parameters of $95^{\circ} \mathrm{C}$ for $5 \mathrm{~min}$ and 35 cycles of $95^{\circ} \mathrm{C}$ for $15 \mathrm{~s}$, annealing at $61^{\circ} \mathrm{C}$, and extension at $72^{\circ} \mathrm{C}$ for $1 \mathrm{~min} 30 \mathrm{~s}$. A final extension for $10 \mathrm{~min}$ at $72^{\circ} \mathrm{C}$ was added at the end of the reaction. The product was verified by gel electro-

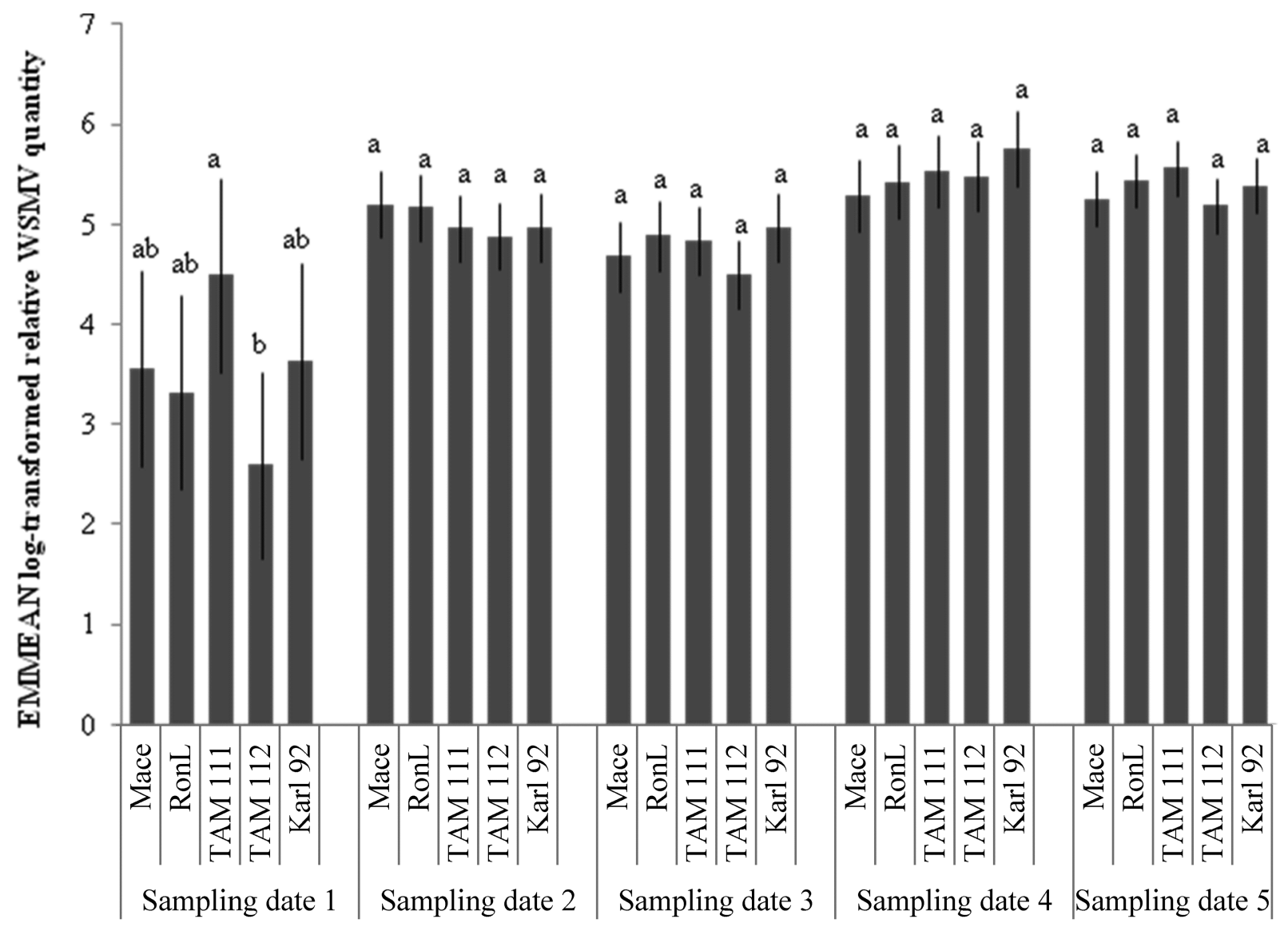

Fig. 1. Combined means for virus quantification values for all varieties at each collection date. Means separation was conducted by least significant difference, $\alpha=0.05$. Significance was to evaluate within groups and columns with the same letter are considered to not be significantly different. Error bars designate $95 \%$ confidence intervals. 
phoresis to be 1,235 bp in length, and then cleaned using QIAquick PCR Purification Kit (Qiagen) and quantified. Number of DNA molecules was calculated based on the average molecular weight of a pair of deoxyribonucleotide (660 Da) for the number of bases in the PCR amplicon, with the following formula: nanograms of DNA $\times$ Avogadro constant $\left(6.023 \times 10^{23}\right.$ molecules/mol $) /$ amplicon base pair length $\times\left(1.0 \times 10^{9}\right) \times(660 \mathrm{Da})$. The calibrator was created by the addition of quantified PCR product DNA with healthy plant DNA to contain 15,000 copies of WSMV template. RQ value was calculated using the $\Delta \Delta \mathrm{C}_{\mathrm{t}}$ method for real-time RQ.

Statistical analyses. All statistical analyses were performed in IBM SPSS software (version 21.0; IBM). A repeated-measures mixed-effects model was used to compare mite numbers and viral quantities among the five evaluated wheat cultivars, experiment, cultivar, sample date, experiment-cultivar, and cultivar-sample date. These factors and interactions were initially included in the model. Largely nonsignificant terms $(P>0.1)$ were removed from the final model in a stepwise approach. Mite numbers and relative WSMV quantifications were log transformed. A value of one was added to all relative WSMV titer quantifications to render all resulting log-transformed numbers positive.

Analysis of variance (ANOVA) was used to compare root and shoot weights among cultivars. Square-root transformed weights provided the closest fit to the normality curve.

\section{Results}

In both studies, disease symptoms were visually detectable approximately 3 weeks after infestation at $28^{\circ} \mathrm{C}$. Overall, virus titer levels differed significantly among wheat cultivars $\left(F_{4,62.47}=2.6, P\right.$ $=0.045)$. There was also a significant effect of sampling date as viral titer increased in all cultivars over time $\left(F_{4,60.6}=37.55, P<\right.$ $0.001)$. No significant effect of experiment $\left(F_{1,66.4}=0.21, P=\right.$ $0.646)$, cultivar-experiment $\left(F_{4,72.1}=0.78, P=0.544\right)$, and cultivar-sampling date $\left(F_{16,60.2}=1.19, P=0.310\right)$ was detected and these variables were removed from the final model in a stepwise approach. Resistant Mace and RonL both contained high virus titers and did not differ from the nonresistant Karl 92. Similar patterns held when temperatures dropped below the resistance threshold (Fig. 1). All cultivars contained virus titer levels which increased with each consecutive sampling date, with the exception of the third and last sample dates (Fig. 1). In the third sample date, mean RQ values for all cultivars showed a decreasing trend after incubation at temperatures of 5 to $7^{\circ} \mathrm{C}$ (Fig. 2). A uniform increase in titer was shared by all cultivars as temperature started to increase in the following sampling date (Fig 2). However, this trend was not statistically significant $(P=0.100)$. During the course of the study, virus titers for Mace and RonL were not found to be significantly different from the other cultivars tested (Fig. 3). However, TAM 112 was found to contain significantly lower overall

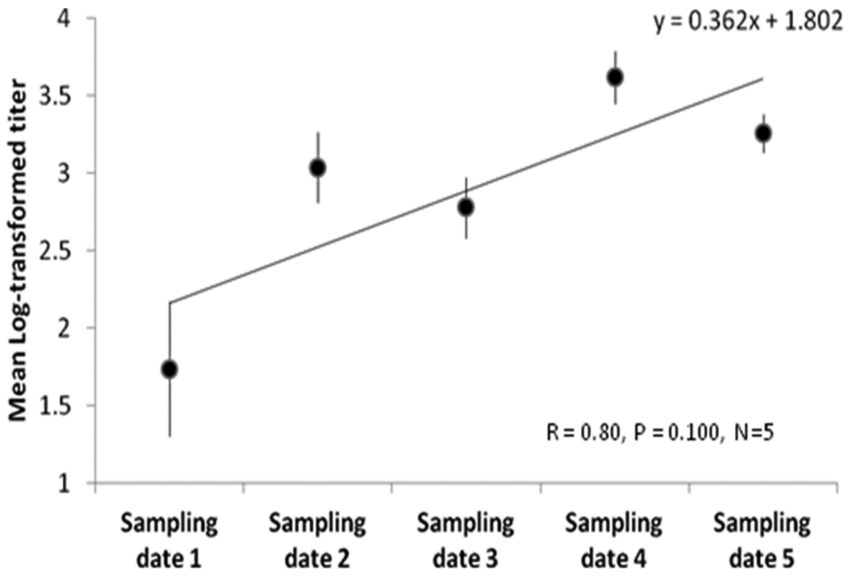

Fig. 2. Mean log-transformed titer levels across varieties within collection dates. Spearman rank correlation $\alpha=0.05$. Error bars designate 95\% confidence intervals. virus titer than the other susceptible varieties, TAM 111 and Karl 92 (least significant difference, $P<0.018$ ). TAM 112 contained the lowest titer during the study, followed by the two resistant cultivars, Mace and RonL. Titer levels in Mace and RonL were not significantly different from those of the susceptible cultivar (Fig. 3 ). Virus titer in TAM 112 was found to be significantly lower than in TAM 111 and Karl 92; however it is important to note that the difference between virus titer in TAM 112 and the susceptible cultivars was only observed when overall virus titer for the entire study was examined (Fig. 3). However, phenotypically, TAM 112 fared better under virus infection than the other cultivars tested, including Mace and RonL, and was the only cultivar that began to produce viable heads. None of the other cultivars developed past Feekes scale 4.5 but TAM 112 continued to develop and, at the time of harvest during the last collection of the first experiment, the majority of plants had progressed into Feekes 10.4 (11; Fig. 4). However, during the second experiment, due to early harvest, these developmental differences were not as dramatic.

Variations in mite densities were significantly affected by both wheat cultivar $\left(F_{4,63.81}=43.21, P<0.001\right)$ and sampling date $\left(F_{4,47.84}=69.46, P<0.001\right)$. No significant effect of experiment

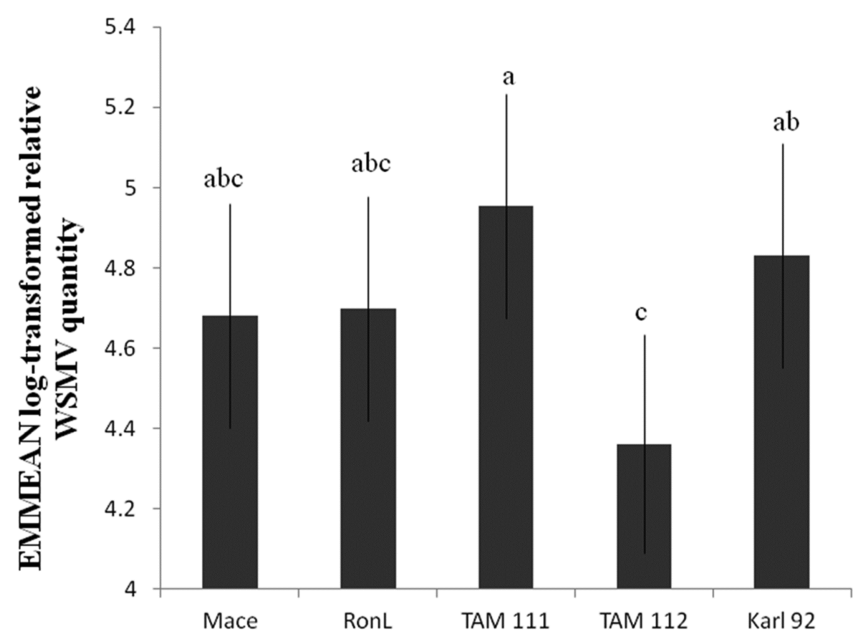

Fig. 3. Overall combined means for virus quantification values for all varieties Means separation was conducted by least significant difference, $\alpha=0.05$. Columns with the same letter are considered to not be significantly different. Error bars designate $95 \%$ confidence intervals.

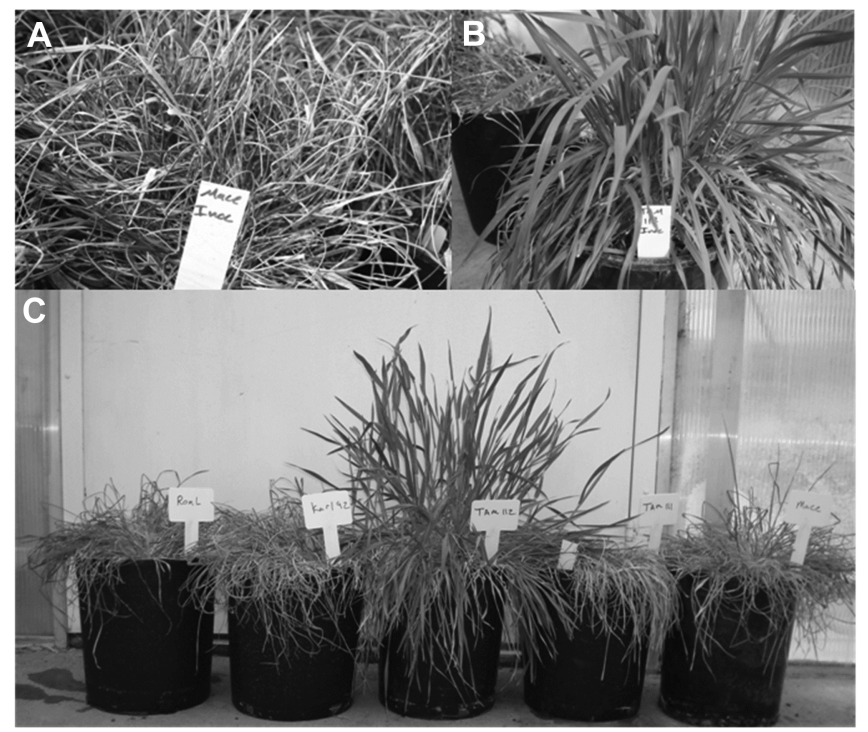

Fig. 4. A, 'Mace' and B, 'TAM 112' wheat after infestation with wheat curl mites. C, Diseases symptoms in 'RonL', 'Karl 92', TAM 112, 'TAM 111', and Mace. Photos were taken approximately 16 weeks after infestation with the wheat curl mite. 
was detected and this factor was removed from the final model $\left(F_{1}\right.$, $59.20=0.244, P=0.623)$. Among-cultivar variations in mite densities remained consistent across sampling dates and between the two experiments, as revealed by the nonsignificant cultivarsampling date $\left(F_{16,42.61}=4.26, P=0.984\right)$ and cultivar-experiment $\left(F_{4,59.20}=2.41, P<0.060\right)$ interactions. Over time, mite numbers were found to be consistently significantly lower for TAM 112 when compared with all other cultivars (Fig. 5). The observed trend was that Mace and TAM 111 contained relatively higher mite populations at all collections (Fig. 4). All cultivars, except TAM 112 , showed significant wheat curl mite feeding damage. In many cases, all leaves were tightly rolled and displayed severe trapping, particularly in the case of Mace (Fig. 4).

ANOVA revealed a significant experiment effect $\left(F_{1,64}=202.26\right.$, $P<0.001)$ in root weight. There was no significant cultivar-experiment interaction $\left(F_{4,60}=1.41, P=0.243\right)$, and this variable was removed from the final model. A significant variation in root weight was detected among cultivars $\left(F_{4,64}=6.95, P<0.001\right.$; Fig. $6)$. TAM112 had the highest root weight when compared with the other cultivars (Tukey's HSD, all $P$ s $<0.019$ ), with the exception from TAM111 $(P=0.685)$. TAM111 root weight was significantly higher than RonL $(P=0.030)$; however, TAM111 formed a statistically homogenous subset with Mace and Karl $92(P=0.056)$ (Fig. $6)$. The actual mean ( \pm standard error $[S E])$ root weights were measured at 29.9 (3.2), 27.3 (4.2), 22.6 (3.7), 20.6(3.7), and 19.8 (4.0) g for TAM 112, TAM 111, Karl 92, Mace, and RonL, respectively.

Similar to root weight, shoot weights also varied significantly among the five cultivars $\left(F_{4,60}=3.27, P=0.018\right)$. Foliar biomass of TAM112 was significantly higher than the rest of the cultivars (Tukey's HSD, $P<0.028$ ). Resistant RonL and Mace had significantly lower combined average shoot weights and were not different from the susceptible control Karl 92. However, there was also a significant experiment effect $\left(F_{1,60}=507.42, P<0.001\right)$ and a cultivar-experiment interaction $\left(F_{4,60}=2.98, P=0.027\right)$. The significant interaction indicated that the variation in shoot weight, observed among cultivars in the first experiment, was not consistent and did not occur in the repeated experiment (Fig. 7).

Across both experiments, the measured nontransformed mean $( \pm$ SE) shoot weights were recorded at $77.6(8.4), 66.4$ (11.2), 65.6 (10.8), and 64.0 (10.5) g for TAM 112, Karl 92, RonL, and Mace, respectively.

\section{Discussion}

The primary objective of this study was to determine whether Mace and RonL, severely infected by WSMV when temperatures were too high for resistance genes to be effective, would recover when temperatures cooled. Unfortunately, both resistant cultivars maintained high virus titers and severe disease symptoms throughout the study, demonstrating the inability to recover from initial infection, even when temperatures fell below the resistance threshold of $25^{\circ} \mathrm{C}$. Once infection occurs, the resistance mechanisms conferred by wsm 1 and wsm 2 are unable to limit virus replication and disease development. Disease development in Mace and RonL significantly reduced root and shoot development and proved to be lethal to the majority of plants tested. Therefore, these cultivars are unlikely to provide the desired disease resistance when used for dual-purpose production in the southwestern Great Plains where temperatures reach, and frequently exceed, threshold levels, especially following planting in late summer and early fall.

Although the resistance in Mace and RonL was ineffective in this study, the reported resistance or tolerance of TAM 112 to WSM (10) was verified by TAM 112's ability to continue development after initial infection. Overall virus titer in TAM 112 was significantly lower than the susceptible varieties; however, when examining individual collection dates, the reduced virus titer was

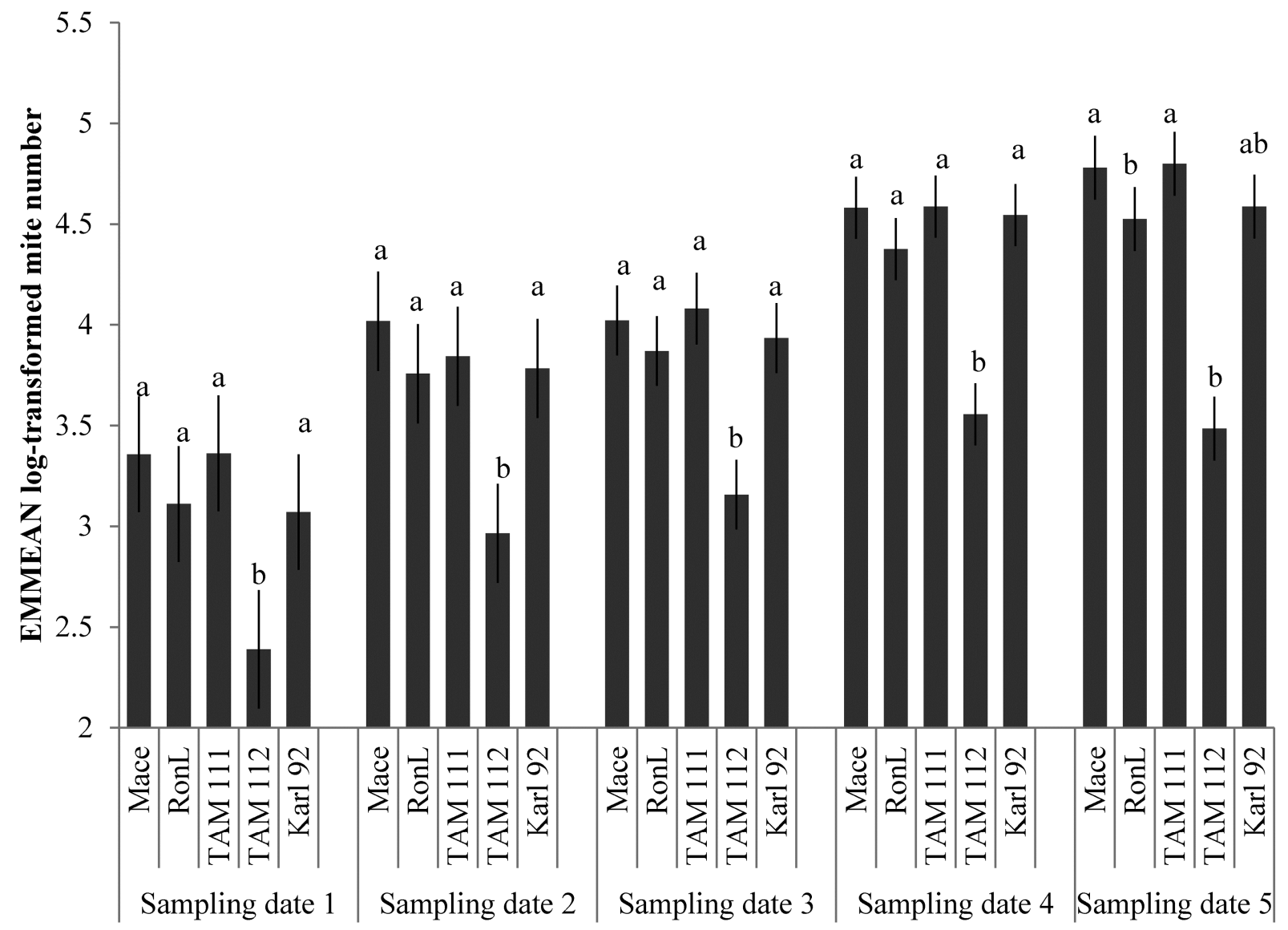

Fig. 5. Log-transformed wheat curl mite numbers for all varieties at each collection date. Means separation was conducted by least significant difference, $\alpha=0.05$. Significance was to evaluate within groups and columns with the same letter are considered to not be significantly different. Error bars designate $95 \%$ confidence intervals. 
only evident during the first collection. This could be due to delayed infection of host plant during mite virus transmission. However, the increases in root biomass and shoot biomass found during the study demonstrate TAM112's ability to continue development following initial virus infection. The difference in shoot development between the TAM 112 and other cultivars was particularly evident during the first experiment when, for the majority of the study, plants were grown in a covered breezeway between two greenhouses and exposed to ambient winter temperatures. However, the reduction in shoot weight was not detectable in the second study, which was conducted entirely in a growth chamber. All cultivars tested during the second experiment experienced reduced disease development, including TAM 112. Because pathogen-plant interactions and subsequent disease severity are known to be affected by environmental factors $(8,9)$, the differences in shoot weight between the repeated studies was possibly affected by variations in temperature, humidity, and light between the first and second study. Alternatively, shoot weight of TAM 112 may have been significantly higher in the first study but not the second, because the second study was terminated approximately 6 weeks earlier than the first. In the first study, the original intention was to continue the study through grain maturity but, because the majority of plants began to die, except for TAM 112, the study was terminated and plants harvested while the TAM 112 cultivar was at Feekes scale stage 10. Because the primary objective of the study was to determine whether Mace and RonL could recover from early infection, and not to quantify resistance in TAM 112, the repeated study was terminated earlier than the first because the primary objective had been achieved.

In studies by $\mathrm{Lu}(10)$, TAM 111 and TAM 112 and parents 'KS96HW10-3' (3) and 'Co960293-2' (18) of Mace and RonL, respectively, were compared with $188 \mathrm{~F}_{2: 3}$ families derived from a cross between Co960293-2 and TAM 111 for symptom severity after mechanical inoculation with WSMV under temperatures conducive for resistance. During the study by $\mathrm{Lu}$, it was determined that the RonL parental line Co960293-2 carried a different gene for resistance to WSMV, wsm2, than that found in Mace, which contained the $w s m 1$ gene. However, both varieties displayed very low disease symptoms at $16^{\circ} \mathrm{C}$. Along with these findings, it was determined that both TAM 112 and TAM 111 contained a partial resistance or tolerance to WSM by displaying disease ratings intermediate to that of the resistant Mace and RonL and the susceptible check Karl 92. ELISA titer values were positively correlated with reductions in disease severity of the cross families tested during Lu's experiment; however, the resistance in TAM 111 and TAM 112 was only subjectively observed and never truly quantified until the present study. During the present study, no increases in shoot

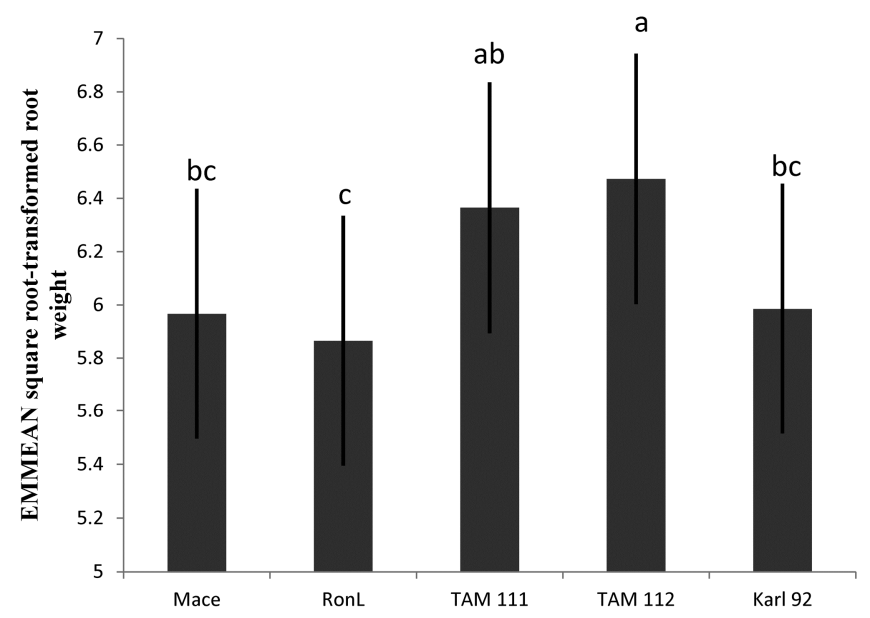

Fig. 6. Combined square root transformed root weights (g) of all cultivars for experiments 1 and 2 . Tukey's honestly significant difference was used for means comparisons, $\alpha=0.05$. Columns with the same letter are considered to not be significantly different. Error bars designate standard error. weight were found in TAM 111 and it was not significantly different from the susceptible control. There was also no reduction in virus titer levels in TAM 111, as was the case for TAM 112. Indeed, TAM 112 was the only cultivar which produced heads while all other cultivars started to senesce and die, particularly in the first experiment. This finding is of a particular importance because the observed resistance to WSMV found in TAM 112, unlike RonL and Mace, did not appear to be temperature sensitive. Thus, TAM 112, which was developed in the Texas Panhandle, will likely have a considerable advantage over RonL and Mace in the warm climate common throughout the southwestern Great Plains, particularly when planted as a dual-purpose crop. However, the resistance genes for WSMV in Mace and RonL do provide adequate resistance when plants are grown in cooler temperatures in more northerly production regions, or for grain only in the southern Great Plains. This demonstrates the importance of regional adaptation and crop end use in making cultivar selections. It is also important to remember that TAM 112 does not contain a high level of resistance to WSMV and, alone, it would not be an adequate source of protection during times of heavy disease. TAM 112 is still capable of becoming infected with WSMV; however the quantitative resistance documented in the study explains breeders' reports of field tolerance inherent in TAM 112 during disease epidemics. This resistance, along with other management strategies, could be useful in control of this disease.

Late-season planting during cooler temperatures is a common management strategy to avoid infection by WSMV. It has been reported that lower temperatures reduce wheat curl mite populations and limit their movement (7). However, in this study, wheat curl mite numbers continued to increase, even as temperatures decreased, but WSMV titer declined at temperatures below $7^{\circ} \mathrm{C}$, a pattern which was consistent across all cultivars. Therefore, the observed reduction of disease incidence with late plantings may be not only due to a reduction of mite numbers but also a result of reduced virus transmission and subsequent infection at cooler temperatures. An important difference between the current study and those conducted by Seifers et al. $(17,18)$, to determine temperature
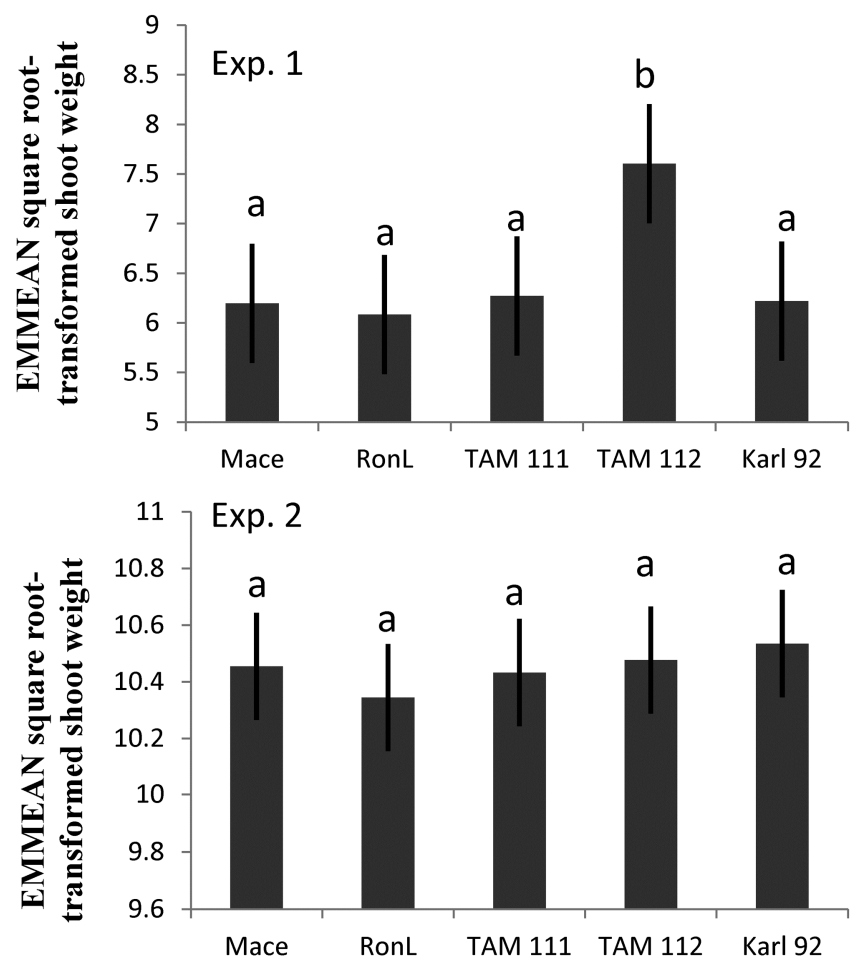

Fig. 7. Square root transformed shoot weights for all varieties for experiments 1 and 2. Tukey's honestly significant difference was used for means comparisons, $\alpha$ $=0.05$. Columns with the same letter are considered to not be significantly different. Error bars designate standard error. 
sensitivity in resistant cultivars, was the use of vector inoculation. This allowed observation of not only the effects of virus infection but also vector-host interactions.

In all of Seifer's studies, plants were inoculated mechanically with WSMV but, in the current study, infective mites were used to naturally infect wheat plants with WSMV. This method was used to more closely mimic a natural field scenario and it led to the unexpected but highly significant finding of wheat curl mite resistance in TAM 112. During the course of this study, wheat curl mite numbers steadily increased on all cultivars. However, on TAM 112, mite numbers consistently remained significantly lower than on other cultivars. Lower mite numbers on TAM 112 resulted in less mite damage when compared with other cultivars (Fig. 3B), particularly Mace and TAM 111, both of which supported exceptionally high numbers of mites throughout the study, averaging approximately 85,000 and 87,000 , respectively, during the final collection, followed by Karl 92 (averaging 60,000). At this time, it is unknown how mite number affects virus titer within different cultivars and disease development. However, these high numbers are a testament to the reproductive capability of the wheat curl mite and demonstrate its potential to rapidly spread WSMV (21). The non-temperature-sensitive resistance in TAM 112 to both the vector and WSMV makes this cultivar suitable for a wide range of climates. Furthermore, the resistance to the wheat curl mite found in TAM 112 will have a dramatic impact, not only in the control of WSM but also on all mite-vectored virus diseases of wheat, by reducing vector populations and movement (4).

\section{Acknowledgments}

This research was supported by funding from the Texas Wheat Producers Board, the Ogallala Aquifer Program, agreement \#58-6209-2-74, and also a grant from NIFA-AFRI \#2013-68004-20358.

\section{Literature Cited}

1. Burrows, M, Franc, G., Rush, C., Blunt, T., Ito, D., Kinzer, K., Olson, J., O'Mara, J., Price, J., Tande, C., Ziems, A., and Stack, J. 2009. Occurrence of viruses in wheat in the Great Plains region, 2008. Online. Plant Health Progress. Online publication. doi:101094/PHP-2009-0706-01-RS

2. Fuentes-Bueno, I., Price, J., Rush, C. M., Seifers, D., and Fellers, J. 2011. Triticum mosaic virus isolates in the Southern Great Plains. Plant Dis. 95:1516-1519.

3. Graybosch, R. A., Peterson, C. J., Baenziger, P. S. Baltensperger, D. D., Nelson, I. A., Jin, Y., Kolmer, J., Seabourn, B., French, R., Hein, G., Martin, T. J., Beecher, B., Schwarzchar, T., and Hesop-Harrison, P. 2009. Registration of 'Mace' hard red winter wheat. J. Plant Regul. 3:51-56.

4. Harvey, T. L., Martin, T. J., and Seifers, D. L. 1994. Importance of plant resistance to insect and mite vectors in controlling virus diseases of plants: resistance to the wheat curl mite (Acari: Eriophyidae). J. Agric. Entomol. 11:3 271-277.

5. Harvey, T. L., Seifers, D. L., and Martin, J. T. 2001. Host rage differences between two strains of wheat curl mites (Acari: Eriophyidae). J. Agric. Urban Entomol. 18:1 35-41.

6. Harvey, T. L., Seifers, D. L., Martin, T. J., Brown-Guedira, G., and Gill, B.
S. 1999. Survival of Wheat curl mites on different sources of resistance in wheat. Crop. Sci. 39:1887-1889.

7. Hunger, R. M., Sherwood, J. L., Evans, C. K., and Montana, J. R. 1992. Effects of planting date and inoculation date on severity of wheat streak mosaic in hard red winter wheat cultivars. Plant Dis. 76:1056-1060.

8. Laine, A.-L. 2007. Pathogen fitness components and genotypes differ in their sensitivity to nutrient and temperature variation in a wild plant-pathogen association. J. Evol. Biol. 20:2371-2378.

9. Laine, A.-L, Burdon, J. J., Dodds, P. N., and Thrall, P. H. 2011. Spatial variation in disease resistance: from molecules to metapopulations. J. Ecol 99:96-112.

10. Lu, H., Price, J., Devkota, R., Rush C. M., and Rudd, J. 2011. A dominant Gen for resistance to Wheat streak mosaic virus in winter wheat line CO960293-2. Crop Sci. 51:5-12.

11. Miller, T. D. 1999. Growth stages of wheat: identification and understand ing improve crop management. Reprint from: Better Crops with Plant Food, 1992. Texas AgriLife Ext. Serv. Bull. SCS-1999-16.

12. Nanassy, O. Z., Haydock, P. V., and Reed, M. W. 2007. Capture of genomic DNA on glass microscope slides. Anal. Biochem. 365:2 240-245.

13. Price, J. A., Smith, J., Simmons, A., Fellers, J., and Rush, C. M. 2010 Multiplex real-time RT-PCR for detection of Wheat streak mosaic virus and Triticum mosaic virus. J. Viro. Methods 165:198-201.

14. Price, J. A., Workneh, F., Evett, S. R., Jones, D. C., Arthor, J., and Rush, C. M. 2010. Effects of Wheat streak mosaic virus on root development and water-use efficiency of hard red winter wheat. Plant Dis. 94:766-770.

15. Seifers, D. L., Harvey, T. L., Martin, T. J., and Jensen, S. G. 1997. Identification of the wheat curl mite as the vector of the High Plains virus of corn and wheat. Plant Dis. 81:1161-1166.

16. Seifers, D. L., Martin, T. J., Harvey, T. L., Fellers, J. P., and Michaud, J. P. 2009. Identification of the wheat curl mite as the vector of Triticum mosaic virus. Plant Dis. 93:25-29.

17. Seifers, D. L., Martin, T. J., Harvey, T. L., and Gill, B. S. 1995. Temperature sensitivity and efficacy of wheat streak mosaic virus resistance derived from Agropyron intermedium. Plant Dis. 79:1104-1106.

18. Seifers, D. L., Martin, T. J., Harvey, T. L., Haber, S., and Haley, S. D. 2006 Temperature sensitivity and efficacy of Wheat streak mosaic virus resistance derived from CO960293 wheat. Plant Dis. 90:623-628.

19. Skare, J. M., Wijkamp, I, Denham, I., Rezende, J. A. M., Kitajima, E. W. Park, J., Desvoyes, B., Rush, C. M., Michels, G., Scholthof, K. G., and Scholthof, H. 2006. A new eriophyid mite-borne membrane-enveloped virus-like complex isolated from plants. Virology 347:343-353.

20. Slykhuis, J. T. 1955. Aceria tulipae Keifer (Acarina: Erio-. Phyidae) in relation to the spread of wheat streak mosaic. Phytopathology 45:116-128.

21. Somsen, H. W., and Sill, W. H., Jr. 1970. The wheat curl mite, Aceria tulipae Keifer, in relation to epidemiology and control of wheat streak mosaic. Kans. Agric. Exp. Stn. Res. Publ. 162.

22. Tatineni, S., Graybosch, R. A., Hein, G. L., Wegulo, S. N., and French, R. 2010. Wheat cultivar-specific disease synergism and alteration of virus accumulation during co-infection with Wheat streak mosaic virus and Triticum mosaic virus. Phytopathology 100:230-238.

23. Velandia-Parra, M., Rejesus, R., Jones, D. C., Price, J. A., Workneh, F., and Rush, C. M. 2010. Economic impact of the Wheat streak mosaic virus in the Texas High Plains. Crop Prot. 29:699-703.

24. Workneh, F., Jones, D. C., and Rush, C. M. 2009. Quantifying wheat yield across the field as a function of wheat streak mosaic intensity: a state space approach. Phytopathology 99:432-440.

25. Workneh, F., Price, J. A., Jones, D. C., and Rush, C. M. 2010. Wheat streak mosaic: a classic case of plant disease impact on soil water content and crop water-use efficiency. Plant Dis. 94:771-774. 